\title{
成人喉頭乳頭腫ウイルスのDNA診断
}

\author{
杉田 麟也・荻原 徹・深本 克彦 \\ 中井川弘毅・石 和久*
}

\section{DNA Evaluation for Human Papilloma Virus Infection in Adult Laryngeal Papilloma}

\author{
Rinya Sugita, Tohru Ogiwara, Katsuhiko Fukamoto, \\ Kouki Nakaigawa and Kazuhisa Ishi \\ (Juntendo Urayasu Hospital, Juntendo University School of Medicine)
}

Tissues from patients with adult-onset type laryngeal papilloma were examined for the presence of human papillomavirus (HPV).

The presence of HPV DNA was determined by in situ hybridization with biotin-labelled HPV DNA probes and by dot blot hybridization with ${ }^{32} \mathrm{P}$-labelled HPV DNA probes.

Two cases of adult-onset type multiple laryngeal papilloma were positive for HPV-6, but a case of single laryngeal papilloma was negative for HPV.

Key words: laryngeal papilloma, human papilloma virus, in situ hybridization, dot blot hybridization, Southern blot hybridization

\section{はじめに}

ヒトパピローマウイルス (human papilloma

virus : HPV) はヒトの粘膜や皮膚の上皮に発 生する良性の腫瘍から分離されるウイルスであ る. HPV感染は婦人科領域での研究が進んで おり，良性腫瘍ばかりでなく子宮頸癌組織に存 在することが明らかになっている.

HPV と耳鼻咽喉科領域疾患との関連につい て注 5,6 歳までの発症が半数を占める若年性 喉頭乳頭腫の場合に尖圭コンジローマを有する 母体の産道での垂直感染であることが知られて いる. 他方, 成人発症型喉頭乳頭腫から HPV を検出したといら報告も若干みられるが，現在
のところ感染経路の解明が不十分である.

著者らは, このたび成人型乳頭腫例から HPVを検出しえたので報告し, 若干の考察を 加觉る。

対 象

昭和59年 5 月中旬から平成 2 年 4 月末までに 順天堂大学医学部付属順天堂浦安病院耳鼻咽喉 科で手術を実施した喉頭乳頭腫患者のうち, 組 織診断で典型的な乳頭腫の像を呈した 3 例であ る.

\section{研究方法}

手術的に摘出した標本に HE 染色を抏こな い, 乳頭腫の所見が得られた症例にDNA 
hybridization 法を実施した。すなわち，in situ hybridization 法 (Vira type ${ }^{\circledR}$, 東レ) を当院で, 同時に dot blot hybridization 法 (Vira pap ${ }^{\circledR}$, 東レ)扐よび Southern blot hybridization法を SRL 社で実施した. in situ hybridization 法, dot blot hybridization 拈よび Southern blot hybridization 法の手技は表 1 ，表 2 に示した ごとくである. 用いた DNA プローブのタイプ は $6,11 ， 16 ， 18 ， 31 ， 33 ， 35$ である1).

\section{結 果}

HPVの感染の有無を検討した 3 例は表 3 の ごとくである. 症例 1 は73歳の男性で72歳の頃

表 1 in situ hybridization 法

Vira type ${ }^{\circledR}$ は HPV-6，11型をふくむプ ローブ，16と18型，31，33と35型をふくを プローブからなる.

1. 前処理
a ．切片スライドのベーク
b. 脱パラフィン
c. 脱キシレン
d. 風乾
e. 消化液反応
f. T B S 洗净
g. 脱水
$\mathrm{h}$. 風乾

2. ハイブリダイゼーション
a . H P V probe滴下
b.カバーグラスをかける
c. heating 処理
d. 湿潤箱にて反応
e.カバーグラスをはずし、probe を洗う
f . T B S 洗净

3 . 同定
a 、組織のまわりをふきとる
b. Detection solution滴下
c . 湿潤箱にて反応
d. 基質液反応
e. 蒸留水洗净

4. 後処理
a. 後染 N F R
b. 蒸留水洗净
c. 脱水…透徹…封入

から嗄声を自覚し徐々に増強してきた。腫瘍は 右声帯に限局した樹針状の白色乳頭腫で成人単 発型であった：腫瘍を顕微鏡下喉頭微細手術で 切除したが，短期間に再発したので喉頭截開術 にて摘出した。 in situ hybridization 法による HPV検索は陰性であった。

症例 2,3 は両側声带と前交連の乳頭腫でい ずれも男性であって，成人多発型であった，病 理組織学的に koilocytusis を認め(図 1 ), in situ hybridization 法でいずれも HPV-DNA 6 型と11型のシグナル陽性であった（図 2 ).

SRLで実施した dot blot hybridization 法では いずれも陽性で，また Southern blot 法ではそ れぞれ 6 型が陽性であった。

\section{考察}

喉頭乳頭腫は, 発症年齢や臨床像の相違によ って 4 つ分類できる．若年性多発型，若年性 単発型，成人多発型括よび成人単発型である。 若年性喉頭乳頭腫は生後 6 力月から 4,5 歳の 間に発症する例が $31 \sim 51 \%$ と多く，成人型との 発症年齢の境は20歳とされている2).

若年性はその汪とんどが多発性，再発性で難 治性であり，この若年性多発型乳頭腫の発症に HPVの感染が大きな役割を担う。すなわち， 性交為感染で生じた尖圭コンジローマを有する 母体の産道での垂直感染が原因である，その根 拠として尖圭コンジローマから分離される

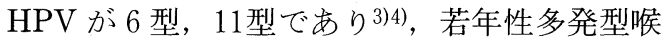
頭乳頭腫から検出した HPV も同じ型であるこ と, 帝王切開で出産した子供には喉頭乳頭腫は 明らかに少ないこと5)6)，などである。

HPVの研究は 1980 年代に入って進歩した。 Mounts ら (1982) ${ }^{3)}$ は初めて若年および成人喉 頭乳頭腫の両方に Southern blot 法によって HPV-DNAを，また Steinberg ら (1983)7) も若 年, 成人型に Southern blot 法で HPV-DNA を検出した。

本邦でも Nakajima ら (1985) ${ }^{8)}$ は成人型12例 中 3 例飞 papillomavirus genus specific common antigen を検出, その 3 例は多発型乳頭腫 
表 2 DNA hybrid 法の実験行程

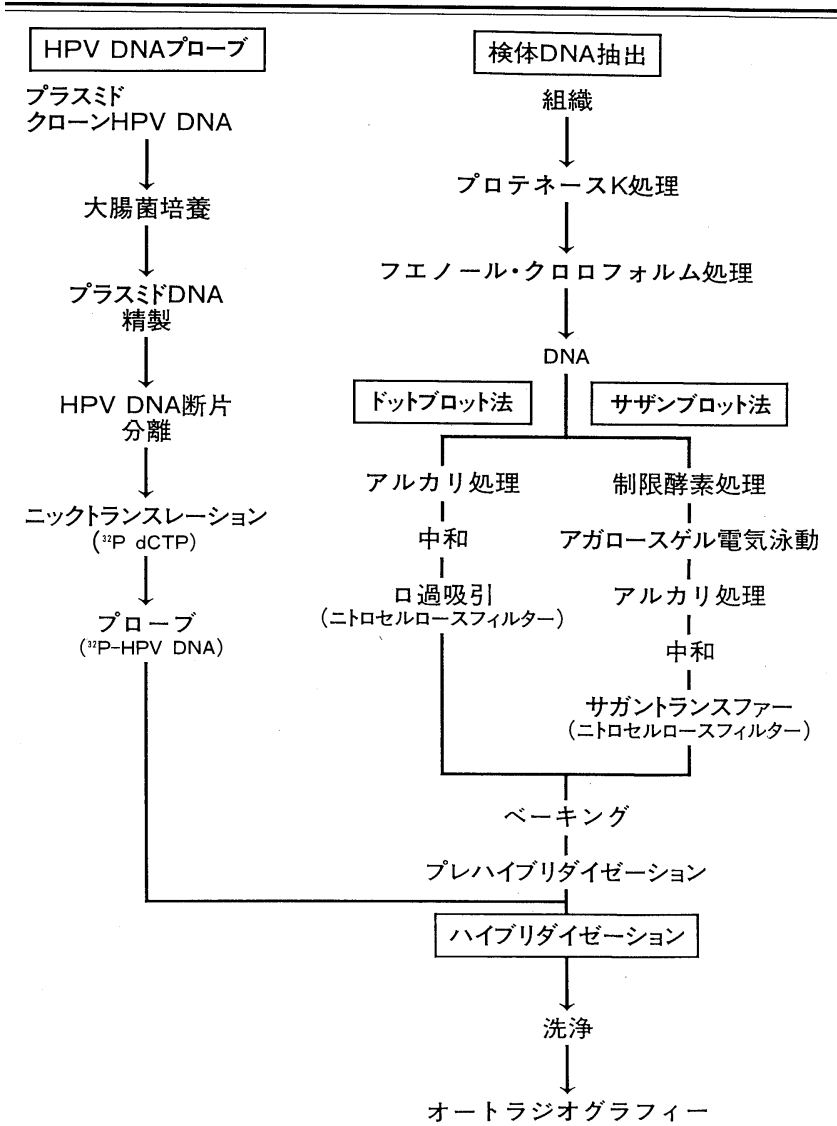

表 $3 \mathrm{HPV}$ を検索した成人喉頭乳頭腫症例

多発型の 2 例で, HPV-6 型を検出した.

\begin{tabular}{|c|c|c|c|c|c|c|}
\hline 症 例 & $\begin{array}{l}\text { 年齢 } \\
\text { 性別 }\end{array}$ & $\begin{array}{l}\text { 発症 } \\
\text { 年齢 }\end{array}$ & 喫煙有無 & 病変部位 & 治 療 & HPV-DNA \\
\hline 1. A.O. & $\begin{array}{r}73 \\
\text { 男性 }\end{array}$ & 73 & 有り & 右声帯 & $\begin{array}{c}\text { 1. ラリンゴマイクロ } \\
\text { サージュリー } \\
\text { 2. 矫頭截開術 }\end{array}$ & 陰性 \\
\hline 2. A.N. & $\begin{array}{c}56 \\
\text { 男性 }\end{array}$ & 55 & 有り & $\begin{array}{l}\text { 両側声帯 } \\
\text { 前交連 }\end{array}$ & $\begin{array}{l}\text { ラリンゴマイクロ } \\
\text { サージュリー }\end{array}$ & $\begin{array}{l}\text { 陽性 } \\
\text { ( } 6 \text { 型) }\end{array}$ \\
\hline 3. S.K. & $\begin{array}{l}24 \\
\text { 男性 }\end{array}$ & 23 & $\begin{array}{c}\text { 有り } \\
\text { 18歳より }\end{array}$ & $\begin{array}{l}\text { 両側声帯 } \\
\text { 前交連 } \\
\text { 浸潤性 }\end{array}$ & $\begin{array}{l}\text { ラリンゴマイクロ } \\
\text { サージュリー }\end{array}$ & $\begin{array}{l}\text { 陽性 } \\
\text { ( } 6 \text { 型) }\end{array}$ \\
\hline
\end{tabular}




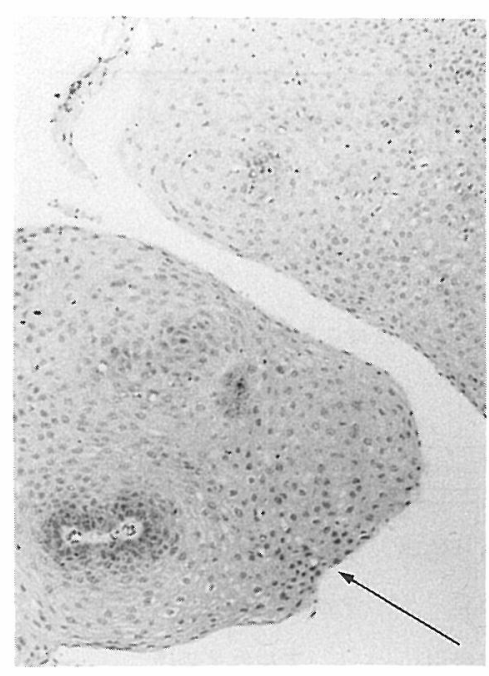

HE 染色 $\times 100$

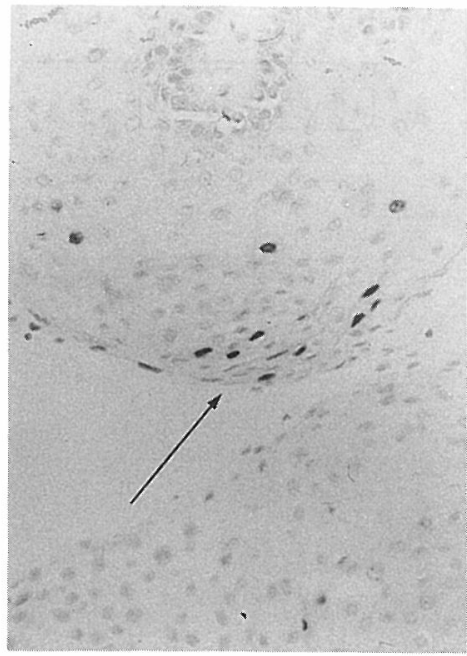

in situ hybridization

図 1 症例 2 の $\mathrm{HE}$ と in situ hybridization 法

左図の HEでは, 肥厚増生した扁平上皮の表層から中層にかけて細胞 は koilocytosis(矢印)を示す。

右図の in situ hybridization 法で, koilocytosis を示寸細胞の核内に黒 紫色 (矢印)のHPV-DNAの陽性像がみられる(type 6/11). Southern blot 法は 6 型であった。

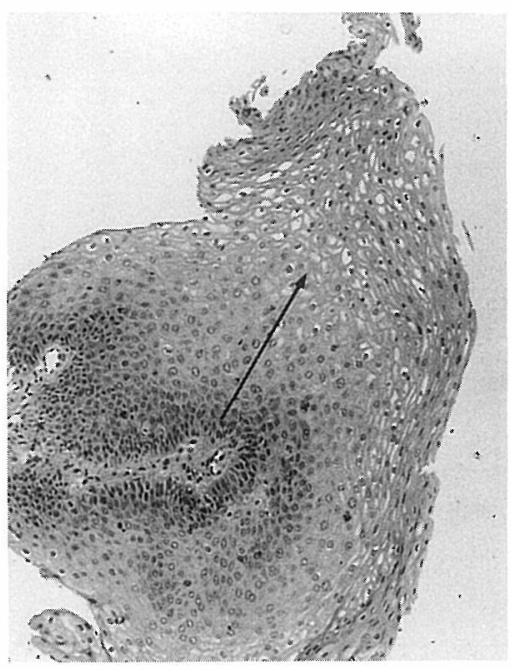

HE 染色 $\times 100$

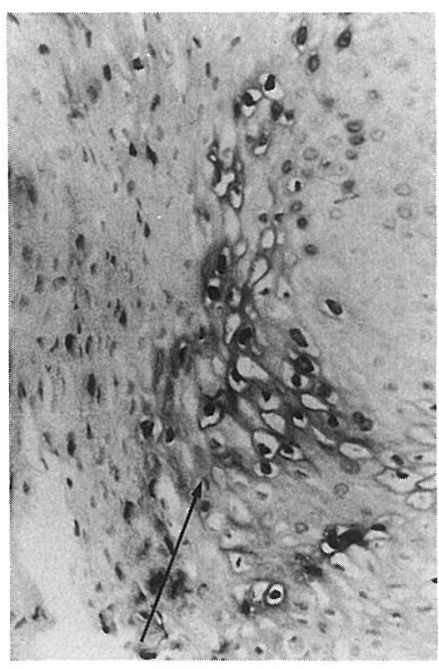

in situ hybridization

図 2 症例 3 の $\mathrm{HE}$ と in situ hybridization 法

左図の HE では表層から中層にかけての細胞は koilocytosis を示す(矢 印).

右図の in situ hybridization では koilocytosis を示す細胞の核内に黒紫 色(矢印)の HPV-DNA 陽性像がみられる(type 6/11). Southern blot 法 では 6 型であった。 
であった. 大谷地ら $(1988)^{9)}$ は小児喉頭乳頭腫 2 例から Southern blot 法により HPV-2 型を, Tsutsumi ら (1989) 10) は成人多発型乳頭腫 8 例 中 6 例で HPV-11 型を検出しているが, 単発 型は11例すべてが HPV-DNA 陰性であった。 古田ら (1989) ${ }^{11)}$ は著者らと同様に in situ hybridization 法を用い成人多発型の 7 例中 5 例 (71 \%)で HPV-6，11型を検出している.

著者らは成人多発型 2 例中 2 例でキットを用 いての in situ hybridization 法で HPV-6 型また は11型DNAシグナルを検出, さらに Southern blot hybridization 法で 6 型であることを確認 している． 6 型は尖圭コンジローマから検出さ れているHPV-DNA と同型であり, 成人多発 型乳頭腫も産道感染あるいは青年期の口腔性交 による感染を考劣させる結果である. 成人多発 型乳頭腫が出産時の産道感染であれば, 垂直感 染して潜伏していたウイルスの活動が喫煙その 他の刺激により促進され発症するのではないか といら推察も扣こなわれている12).

DNAの診断法について述べる. 感染症に対 するDNA 診断法はウイルスのみならず，肺炎 マイコプラズマ，結核菌などの診断にも用いら
れるよらになっている. 主に dot blot 法と in situ hybridization 法であり,このほかに Southern blot 法执よび Northern blot 法とがある.

DNA 診断法に拈いて DNA プローブは大量 に精製することができ，またかなり分解したゲ ノム (50ヌクレオチド程度)でも検出可能である. 唯一の欠点は, 現在アイソトープ標識プローブ が広く使用されていることであるが，今後は酵 素標識のプローブに変っていくものと思われる. このたび著者が使用したキッドの in situ hybridization 法のプローブ標識はビオチンといら酵 素であり, dot blot 法は ${ }^{32} \mathrm{P}$ を使用している。

主な測定法の長所, 短所は表 4 のごとくであ る.

$1)$ in situ hybridization 法

本法にはいくつかの方法があるが, 通常はパ ラフィンブロックからの組織を用いて標的 DNAの検索を行ら。したがって検索 DNAの 組織像を損らことなく, 感染細胞の形態的特徵, さらに細胞㧍よび組織中での局在を知ることが 出来る. 本法の陽性率は dot blot 法と比較する と低く約半分である。われわれが使用した Vira type ${ }^{\circledR}$ (東レ)法は米国で市販されている

表 4 DNA 診断法, 主な測定法の特徴 (石 和久, 他：19901) より転載)

\begin{tabular}{|c|c|c|c|}
\hline & dot blot法 & in situ hybridization 法 & Southern blot法 \\
\hline 利点 & $\begin{array}{l}\text { 1. 測定操作が簡易であり } \\
\text { 操作時間が短い } \\
\text { 2.多量検体の処理が可能 } \\
\text { 3.少量の細胞数または } \\
\quad \text { 組織で測定可能 } \\
\quad\left(10^{5} \text { 以上または1pgDNA) }\right.\end{array}$ & $\begin{array}{l}\text { 1.測定操作が簡易であり } \\
\text { 操作時間が短い } \\
\text { 2.病理組織像と対比でき } \\
\text { 局在が明確 } \\
\quad \text { (特に酵素標識の場合) }\end{array}$ & $\begin{array}{l}\text { 1. ウィルスの型別が } \\
\text { 可能 } \\
\text { 2. 検出感度がよい }\end{array}$ \\
\hline 欠点 & $\begin{array}{l}\text { 1. ウィルス型別検索が } \\
\text { 不可能 } \\
\text { 2. 組織形態像がみられない }\end{array}$ & 1. 検出感度が低い & $\begin{array}{l}\text { 1. 測定操作が煩雑で } \\
\text { 操作に長時間要す } \\
\text { る } \\
\text { 2. 組織形態像が } \\
\text { みられない }\end{array}$ \\
\hline
\end{tabular}


が本邦では研究用である. Vira type のプロー ブは婦人科領域で使用されているもので，6 型, 11型をふくむプローブ，16と18型，31，33と35 型をふくさプローブである.今後は耳鼻咽喉科 用にプローブの種類を増加させる必要がある.

2) dot blot 法

極めて感度が良く大量のサンプルを迅速にス クリーニングするといら利点がある反面, ウイ ルス属内の特異性を判定するのが困難であると いら久点もある。ささにアイソトープを使用す るので設備の問題もある.

3 ) Southern blot 法

ウイルスの型別や血清学的に区別不能なウイ ルス株間の鑑別の際に用いる. 実際には高分子 DNA を制限酵素で切断し, 電気泳動により分 画してからさらに固相マトリックスにトランス ファしてDNA プローブとハイブリダイズさせ るので精度は高いが迅速性の点で問題がある。

\section{まとめ}

1. 成人単発型喉頭乳頭腫 1 例, 成人多発型 喉頭乳頭腫 2 例について，キットによる in situ hybridization 法 (Vira type ${ }^{\circledR}$, 東 $レ$ ), dot blot hybridization 法(Vira $\operatorname{pap}^{\circledR}$ ，東レ)および Southern blot hybridization 法を用いてヒトパ ピローマウイルス感染を検討した.

2 . 単発型はHPV-DNA 陰性であったが, 多発型の 2 例は in situ hybridization 法で HPV -6, 11型のシグナル陽性, dot blot hybridization 法陽性で, Southern blot hybridization 法 でHPV-6 型を確認した.

3. 感染経路として出産時の産道での垂直感 染, あるいは成人後の口腔性器接触による感染 が考えられた。

4. in situ hybridization 法は測定操作が簡 易で操作時間が短く, 病理組織像と対比できウ イルスの局在部位が明確である. Vira pap 法 はキットで使いやすいが，プローブの種類を耳 鼻科用に増加する必要がある。

稿を終えるにめたり御指導, 御校閲をいただいた 市川銀一郎教授潐謝致します。

\section{文献}

1）石和久, 霜多広, 川島徹: STD 臨床 検查一最近の進歩一. Current Laboratory Medicine 8 : 58 62, 1990.

2) Morgan $\mathrm{AH}$ and Zitsch $\mathrm{RP}:$ Recurrent respiratory papillomatosis in children; a retrospictive study of management and complications. Ear Nose and Throat J $65: 403 \sim 410$, 1986.

3) Mounts P, Shah K and Kashima H : Viral etiology of juvenile and adult-onset squamous papilloma of the larynx. Proc Natl Acad Sci USA 79 : 5425 5429, 1982.

4) Gissmann L, Wolnik L, Ikenberg $H$, et al : Human papilloma virus type 6 and 11 DNA sequences in genital and laryngeal papillomas and in some cervical cancer. Proc Natl Acad Sci USA $80:$ 560 563, 1983.

5) Shah K : Rarity of cesarean delivery in cases of juvenile-onset respiratory papillomatosis. Obstet Gynecal 68 : 795 799, 1986.

6) Quick CA : Relationship between condylomata and laryngeal papillomata. Ann Otol 89: 467 $\sim 471,1980$.

7) Steinberg BM, Topp WC, Schmeider PS, et al : Laryngeal papilloma virus infection during clinical remission. N Engl J Med 308 : 1261 1264, 1983.

8) Nakajima T, Tsumuraya M, Morinaga S, et al : Papillomavirus infection among Japanese; an immunohistochemical study for papillomavirus genus-specific antigen in human surface epithelial lesions. Jpn J Cancer Res (GANN) $76: 508 \sim 516,1985$.

9) 大谷地直樹, 三浦 功, 矢原三十美, 他 : Human papilloma virus (HPV) を検出した小児 咽頭乳頭腫の 2 例. 日気食会報 $39: 239 \sim 240$, 1988.

10) Tsutsumi $K$, Nakajima $T$, Gotoh $M$, et al : In situ hybridization and immunohistochemical study of human papillomavirus infection in adult laryngeal papillomas. Laryngoscope 99:80 85, 1989.

11）古田 康, 犬山征夫, 長嶋和郎: 乳頭部領域の 
乳頭腫病変とヒトパピローマウィルス 一Digoxigenin 標識プローブを用いたウィルス核酸 の検出一. 日耳鼻 $92: 2055 \sim 2063,1989$.

12) Mounts $P$ and Shahk $V$ : Respiratory papillomatosis; etiological relation to genital tract papillomatosis. Prog Med Viral 29 : 90 114,

原稿受付: 平成 3 年 1 月 19 日 原稿採択: 平成 3 年 4 月 3 日 急載 別刷請求先: 杉田麟也 厂279 浦安市富岡2-1-1

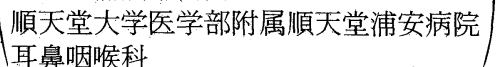
1984. 